\title{
1 Corinthians 14:33b-36 in light of women and church leadership in Nigeria
}

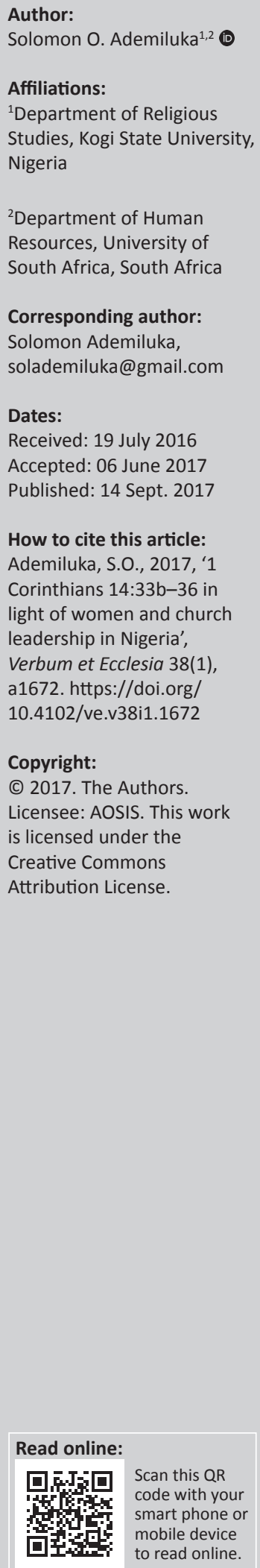

1 Corinthians 14:33b-36 contains the injunction by Paul that women should not speak in the church. In Nigeria, many of the mainline denominations exclude women from church leadership, basing the doctrine on this passage. This research examines the text with a view to assessing its relevance for women's participation in church leadership with a focus on contemporary Nigeria. An examination of the history of the Jews reveals that women had a very small role in religious leadership. However, Jesus in his woman-friendly ministry marked a change in the male-dominated social structure. Paul built upon this, having many women as co-preachers; which would contradict a literal interpretation of 1 Corinthians 14:33b-36. However, the text is best understood from the perspective of the Greek term ekklesia. In its popular context, it refers to the assembly of a Greek city-state in which women were not permitted to speak. In similar Christian assemblies, they were permitted on the basis of the Christian brotherhood. Apparently, in the Corinthian church, women were abusing this privilege by disrupting church services, which warranted Paul's order. This being the case, the crucial issue is the disorderliness being caused by the women, and not their participation. Therefore, in this text it was not the intention of Paul to establish a doctrine disallowing women from participating in church leadership. Hence, for the Nigerian context, the text does not provide a basis for excluding women from church leadership.

Intradisciplinary and/or interdisciplinary implications: This research involves the disciplines of New Testament theology and church history. It examines 1 Corinthians 14:33b-36 with a view to assessing its relevance for women participation in church leadership and anticipates a situation in which all the mainline churches in Nigeria would involve women in church leadership.

\section{Introduction}

\begin{abstract}
${ }^{33 b}$ As in all the churches of the saints, ${ }^{34}$ the women should keep silence in the churches. For they are not permitted to speak, but should be subordinate, as even the law says. ${ }^{35}$ If there is anything they desire to know, let them ask their husbands at home. For it is shameful for a woman to speak in church. ${ }^{36}$ What! Did the word of God originate with you, or are you the only ones it has reached? (1 Corinthians 14:33b-36; Revised Standard Version [RSV])
\end{abstract}

This research seeks to interpret 1 Corinthians 14:33b-36 in relation to women participation in church leadership with particular reference to Nigeria. In Nigeria, there has been the contention as to whether or not women should be involved in church leadership. Majority of denominations involve women one way or the other but some, especially among the mission churches, still believe that the leadership of the church should not be made open to women, basing the doctrine on the Pauline injunction in 1 Corinthians 14:33b-36. The aim of this essay therefore is to examine the text with a view to assessing its relevance for women's participation in church leadership with a focus on contemporary Nigeria.

\section{The issue of women and church leadership in Nigeria}

There are no direct exegeses on 1 Corinthians 14:33b-36 known to me which are done by Nigerians. However, there are indirect reactions to the text especially by church leaders in the context of attitudes toward women participation in church leadership. According to a survey carried out by the present writer (Ademiluka 2007:76-96), this attitude varies according to denominations. The earliest churches are the mission-oriented denominations which adhere strictly to the doctrines and practices introduced by their early missionaries. These ones do not include women in church leadership as a matter of denominational practice, which of course is based on the 1 Corinthians text, among others. This category has churches such as Evangelical Church Winning All (ECWA), the Anglican Communion, the Methodist Church and, especially, the Roman 
Catholic Church. The Anglican and Methodist denominations are particularly adamant in this regard. In 1993, Bishop Haruna, then head of Kwara State Diocese of Anglican Church, ordained three women, but the Anglican House of Bishops annulled the ordination. Similarly, in 1994, the synod of the Methodist Diocese of Kwara and Kogi States took the decision to start the ordination of women, but the headquarters of the church rejected it (Omotoye 19961999:65). Others, such as the Baptist Convention, involve women at the lower level of the hierarchy, giving a woman the title of deaconess.

The inclusion of women started with the Pentecostal churches, and it was natural in some cases. This is true particularly of the Cherubim and Seraphim Church (C\&S) and the Christ Apostolic Church (C. A. C.). In fact, it was the former that laid the foundation for the practice in Nigeria of a woman, AbiodunAkinsowon, being a co-founder of the church, and it has since involved women in its leadership. Today, women are given the title of Mother in Israel in local branches of the Cherubim and Seraphim Church, which is high up in the leadership hierarchy (Ademiluka 2007:79-80). Apart from this, there are numerous $C \& S$ churches founded by women all over Nigeria. At the inception of Christ Apostolic Church (C. A. C.), women were not given place in its leadership, but with time, as female members began to exhibit the gift of prophecy, they began to be involved. Today, they are not only appointed as deaconesses; women have actually founded many C. A. C. branches (Olajubu 1991:79, 1993:142).

In the same vein, most of the neo-Pentecostal denominations in Nigeria today include women in all levels of leadership. In some of them women are even given the highest leadership title of the church. This is the case in Living Faith Church, Christ Embassy, Foursquare Gospel Church, The Redeemed Christian Church of God, Rhema Chapel, Mountain of Fire and Miracles, among others (Ademiluka 2007:79-80). It is important to note, however, that their reason for including women is simply an adaptation to the practice of their foreign founders, as in the case of the mission-oriented denominations. That is not to say, however, that there are no exceptions in the neo-Pentecostal fold. There are those of them who exclude women from leadership on the basis of 1 Corinthians 14. For example, New Testament Christian Mission, Deeper Life Bible Church and End-Time Message Believers' Fellowship (EMBF) still practise male domination. In fact, the EMBF is not only opposed to the inclusion of women in church leadership but vehemently criticises churches that do. Hence, as far as one of its pastors, Pastor Ojo, is concerned such churches are not of God, for they contradict the word of God (Ademiluka 2007:78).

Thus, in Nigeria the denominations are still divided on the issue of the inclusion of women in church leadership. Whereas those who exclude women base their non-inclusion practice on the 1 Corinthians text, those who practice women inclusion believe that this text needs not be an impediment to women playing leadership roles in the church. However, it is important to clarify that women participation in church leadership in Nigeria hardly means more than giving them titles and making them leaders of women organisations within the church; women rarely head churches except those they establish themselves, and these are mostly limited to the C\&S and C. A. C. Thus, male domination is still predominant in church leadership in Nigeria, which may be a reflection of the patriarchal nature of the Nigerian society as in Africa at large.

\section{The status of women in Judeo- Christian traditions}

To understand the Corinthians text in proper perspectives, in this section we shall trace the Judeo-Christian history as it relates to the status of women. In pre-monarchical Israel, women were household managers, as the family household was the key entity in providing for almost all needs of the members. However, a number of women also performed significant leadership roles even at the 'national' level (Masenya 2013:138). In this regard, Olajubu (1991:75) reiterates the leadership roles of Miriam (Ex 15:1-21), Deborah (Jdg 5) and Esther (Es 4:14, 16). Similarly, Odendaal (1994:256) points out remarkable instances in the Old Testament where women undertook responsibility for themselves and for the nation, even though the tales were told in male contexts. Odendaal makes reference to Ruth, Esther and Deborah, among others. However, with the introduction of male-controlled institutions such as the monarchy and the Jerusalem temple, female visibility and impact receded (Masenya 2013:141). During the monarchy, the female activities of the patriarchal household became less and devalued as compared with the male activities of the public male-operated sphere. Women were excluded from significant temple duties, as the Israelite cult was an essentially male institution, which explains the employment of only male priests (Masenya 2013:143).

Burrows (1982:135) affirms that in the Old Testament, in relation to man and matters of the law, women seem to have been rated rather low. He states that in general the position of women in the Hebrew society was not as high as modern standards would require, or even as high as it was among other ancient people. According to him, the husband was his wife's ba'al (lord), not 'adon (master), the same term that a slave would use for his owner. In other words, the status of a wife in relation to her husband was like that of a slave. In fact, as others have shown, woman in Hebrew society were perhaps rated even lower than a slave. According to Sheila Collins (1972:796), 'Women were regarded as an inferior species to be owned like cattle, incapable of participating in the mysteries of the worship of Yahweh'. Claassens (2013:607-608) employs the daughter of Jephthah narrative (Jdg 11:29-40) to illustrate the 'dehumanizing effects of patriarchy' against the womenfolk. The fact that this young woman has no name attests to how little value she and other women held in a society structured around male honour. And through patriarchy's power Jephthah's daughter loses her life (Claassens 2013:607). In spite of this, as far as the young woman is concerned, in fulfilling the vow he has made to Yahweh, his father is committing a just 
and venerable deed (v.36), thereby embracing patriarchal ideology couched in religious terms.

In the opinion of Masenya (2013:144), in the post-exilic period, with the autonomy and decision-making authority flowing back to the collocation of families from the ruined central power structure, the community-wide authority of women as household managers would also increase. Based on the evidence from Jewish women's lives in the Elephantine documents, women could inherit property (Masenya 2013:148). Relying on the Hebrew term sopheret in Ezra 2:55 and Nehemiah 6:57, Masenya observes that there were female scribes among the returnees from the Babylonian exile. There were also male and female singers (Ez 2:65; Neh 6:67). She has however noted earlier that during this period women were viewed not only as secondary citizens but, in fact, as men's property (Masenya 2013:146). Hurley affirms that from the post-exilic period onwards the status of women was really low. The part of women in synagogue worship was strictly receptive. Even the oral reading of scripture was not for women. Women were generally assumed by the rabbis to be persons incapable of learning about religious things. Hurley quotes Rabbi Eliezer as saying:

It is better that the words of the law should be burned ... than they should be given to women; ... if a man gives her daughter knowledge of the law it is as though he taught her lechery. (Hence) every day a Jewish male thanked God that he had not been created a gentile, slave or woman. (Hurley 1975:63, 71)

This view is in line with Baumert's assertion that:

In Judaism there were firmly established customs to the effect that women by themselves could not conduct an official worship service, but could only come together for prayer ... (whereas) a service in the synagogue required the presence of at least ten men ... (Baumert 1996:210)

That was the status of women in the society in which Jesus lived. Hence, we can say that Jesus' attitude towards women violated the contemporary norms, for he related with men and women equally. Jesus healed women as he healed men; he even allowed a woman who had haemorrhage, and was thus ceremonially unclean, to touch his clothes (Mt 9:20-22). He protected a woman who was caught in adultery, and would have been stoned to death (Jn 8:3-11). It is important to note that Jesus continued to talk to her after the others had left, just as he conversed with the Samaritan woman when no one else was with them (Jn 4). According to Powers (1996:17), this was contrary to the culture of the day in which men were discouraged from talking with women; conversation with a woman in a public place was particularly scandalous even if she was a member of one's family. Jesus related very closely with the family of Mary and Martha, the sisters of Lazarus whom he later raised from death (Lk 10:38-42). A group of women accompanied him and his disciples on some of their travels and ministered to their needs (Lk 8:1-3).

After Jesus, women continued to play significant roles in evangelism. Paul preached to women who later became part of his ministry. At Philippi, Lydia and some other women were converted and her house became the home of the new church (Ac 16:13-15, 40). We also read the work of Priscilla and her husband Aquila (Ac 18:26), and the four daughters of Philip who were prophetesses (Ac 21:9). Some of Paul's letters indicate that there were women who were his fellow workers in evangelism. In Romans 16:1-2, Paul mentions specifically 'our sister Phoebe', who is a deacon of the church at Cenchrea (Romans 16:1-2). The Greek word used here for deacon is diakonos which, according to Manson (1982:952), is a noun of common gender denoting the holder of some office in the local church. Moo (1994:1158) states that in calling Phoebe a diakonos, especially with the official sounding addition 'of the church of Cenchrea', it is more likely that Paul is identifying Phoebe as holding the office of deacon (cf. Stegemann \& Stegemann 1999:396). This is similar to Manson's suggestion that whatever the tasks of this office they were performed by men or women (Manson 1982:952). Romans 16:1-2 may therefore be a pointer to the fact that men as well as women performed the role of a deacon in the hierarchy of leadership in the early church. Romans 16:1-2 may therefore be a basis upon which some denominations in Nigeria appoint women as deaconesses, as mentioned above.

In Romans 16:7, another woman, Junia, is listed with some apostles. In the opinion of Stegemann and Stegemann (1999:395), the title of apostle probably characterises her as an envoy legitimated by an appearance of the resurrected Christ. Thus, she was one of 'the earliest itinerant missionaries, even before Paul himself'. ${ }^{1}$ In Colossians 4:15, Paul also mentions 'Nympha and the church in her house', while in the address of his letter to Philemon (v.2) he includes 'Apphia our sister'. Paul calls some other women - Euodia and Syntyche coworkers (Phlp 4:2), thereby including these individuals as commissioned of God in the common work of missionary proclamation. Also to be counted in the circle of women active in missionary preaching are Mary (Rm 16:6), Tryphyaena, and Persis ( $\mathrm{Rm} 16: 12)$, as they are also characterised by the word kopian (toil), which is said to belong in the context of mission (Stegemann \& Stegemann 1999:395).

Hence, Elizabeth S. Fiorenza is right in asserting that in Paul himself women appear not merely as rich patronesses of the Christian missionary movement but as prominent leaders and missionaries who, in their own right, toiled for the gospel (Fiorenza, cited in Baumert 1996:177). In her own summary:

women were among the most prominent missionaries and leaders in the early Christian movement. They were apostles and ministers like Paul, and some were his coworkers. They were teachers, preachers, and competitors in the race for the gospel. They founded house churches and ... their authority and ministry were neither restricted to women and children, nor exercised only in specific feminine roles and functions. (p. 178)

It is important to note, however, that the same texts upon which Fiorenza based her claims are interpreted differently by S.L. Love (cited by Baumert 1996:179). Love interprets

1. However, the name Junia may be controversial. Some versions (e.g. RSV, NIV, NIB, NJB) use the masculine form, Junias, which seems plausible in view of the phrase NJB) use the masculine form, Junias, which seems plausible in view of the phrase
'my kinsmen'. But some believe it is feminine Junia which is believed to be quite common (Moo 1158). 
these texts within the 'macrosociological perspective' of an urban lifestyle within the framework of an agrarian culture. Similar to the view of Masenya on the role of women in the pre-monarchical and post-exilic Israel, Love affirms that in such a context the role of women is limited to the care for the household, bearing children, and meeting in private, in contrast to public, behavioural expectations. In such cultures, equality and freedom are 'social anachronisms'. Love's position here is buttressed by Stegemann and Stegemann (1999) when they say that:

Ancient Mediterranean societies were characterized by a rather strict differentiation of the social roles and areas of competence assigned to the sexes. The expectation of sex-conforming role behavior was extremely high, and the switching of male and female roles or competences was taboo. (p. 361)

Juxtaposing Fiorenza and Love, it is evident that the activities of women in the ministries of Jesus and Paul constitute an improvement in the status of women in Judaism, and may be seen as the beginning of the revolution which Christianity would bring upon social structures as they relate to the role of women in the church. Baumert (1996:181) seems to recognise this fact when he states that the Christian message has an impact on social structures, but that this impact is indeed no sudden event'. Thus, Jesus in his woman-friendly posture laid the foundation for this impact, and Paul built upon it. It is important to note, however, as Baumert rightly affirms, that neither Jesus nor Paul 'took it as their immediate goal to change social structures', (Baumert 1996:181) but 'they did point to a new direction that was open to further developments in society and the church, developments which in our own day have yet to be fully realized' (Baumert 1996:212). This conclusion that the status of women began to witness an improvement in the ministries of Jesus and Paul anticipates our examination of 1 Corinthians $14: 33 b-36$ as a text most probably reflecting the emerging change in social structures in relation to the roles of women in the church.

\section{The socio-historical context of 1 Corinthians}

According to Carson, Moo and Morris (1992:263), in 146 BCE the Romans utterly destroyed the ancient city of Corinth, killing its citizens or selling them as slaves, with an order prohibiting its reestablishment. However, a century later Julius Caesar founded the city afresh, making it a Roman colony, and from 29 BCE onwards it served as the seat of a proconsul and the capital of the senatorial province of Achaia. The new city was populated by people from the various parts of the empire. Many were freedmen from Rome; Jews were certainly included in the new citizenry. Some Greeks were also residents of the new Corinth, but the Romans dominated the scene with their laws, culture and religion. As MurphyO'Connor (1982:xi) puts it, the new Corinth became a highly developed commercial city, its population made up of onethird free full citizens, one-third freedmen (ex-slaves) and one-third slaves. It was really a 'centre of trade, religion, education, architecture, entertainment and artisanship' (Shillington 2008:152). Carson et al. (1992:263) note that by
29 BCE much of the empire had been thoroughly Hellenised, with Greek as its lingua franca. From Asia and Egypt came various mystery cults, while religious, philosophical and cultural ties were quickly re-established with the rest of the Greek peninsula. There was no landed aristocracy in the new Corinth, but there arose an aristocracy of wealth, and the poor were correspondingly despised or ignored (cf. 1 Cor 11:17-22).

As we read in Acts 18:1-7, Paul founded the church at Corinth after his visit to Athens. This was around 50 CE (Winter 1994:1161). Supporting himself with his trade as a tentmaker or leatherworker, he lived with Aquila and Priscilla, who had recently moved to Corinth from Rome (Ac 18:1-3). However, because of opposition Paul was forced to move his ministry to the house of Titus Justus. His evangelism was so fruitful that many converts were made, notable among them being Crispus, the synagogue ruler and his entire family (Ac 18:7-8). After 18 months' work Paul left Corinth with Aquila and Priscilla for Jerusalem while the work was continued by Apollos, an Alexandrian Jew (Williams 1982:954; Winter 1994:1161; cf. 1 Cor 3:6-11). He did not remain long in Jerusalem but soon returned to his home church in Antioch and shortly after returned to Ephesus. There he began another ministry of 2 and a half years, probably the autumn of 52 to the spring of 55, during which period he wrote 1 Corinthians (Carson et al. 1992:264).

Unfortunately, after Paul left Corinth there arose sharp divisions in the new church, evident in the report brought to Paul by 'some from Chloe's household' (1 Cor 1:11). In it Paul learnt of the party spirit by which various sectors of the church identified themselves with particular leaders, apparently boasting of the superior wisdom of their selfidentification in each case (1 Cor 1:10-17; 3:1-4; cf. Carson et al.1992:259). According to Murphy-O'Connor (1982:xi-xii), there were four factions in the church who gave their allegiance to Paul, Apollos, Cephas, and Christ, possibly each with their own theological stance (cf. 1 Cor 1:12). The party spirit was probably accentuated by the membership of the church which included relatively powerful persons. MurphyO'Connor (1982:x) affirms that some of Paul's converts at Corinth 'were very comfortably off'. They were independentminded and were prepared to take risks to get what they wanted. The author may therefore be correct when he says, 'Conceited, stubborn, over-sensitive, argumentative, infantile and pushy are all adjectives that describe the Corinthian church' (Murphy-O'Connor 1982:ix).

This is the nature of the church to which 1 Corinthians was addressed. That Paul is the author of both 1 and 2 Corinthians is rarely contested. In the first letter, Paul deals with many issues of controversy including sexual immorality (1 Cor 5:1-5; cf. 1 Cor 6:12-20), public litigation among members (1 Cor 6:1-8), uncertainties about the place of marriage and the propriety of eating food that had been offered to idols (1 Cor 7 \& 8), head covering by women, the Lord's Table (1 Cor 11), infatuation with the more spectacular of the charismatic gifts without any profound commitment to 
mutual love (1 Cor 12-14), and some confusion about the nature of the resurrection (1 Cor 15). Our text belongs to the literary unit which addresses the poor ordering of the church's corporate meetings (1 Cor 14:26-40).

\section{Corinthians $14: 33 b-36$ in relation to the role of women in the church}

So far, we have seen that in Jewish traditions women were rated very low in status compared to men. However, the level of activities of women in the ministries of Jesus and Paul marked the beginning of an emerging change in the hitherto male-dominated social structures in the Judio-Christian world. In this section, we shall be examining 1 Corinthians $14: 33 b-36$ in relation to the role of women in the church.

Many commentators recognise 1 Corinthians 14:26-40 as a literary unit in which the author gives injunction on conducting services in a fitting and orderly manner. Most interpreters also agree that verses 33b-36 are 'extremely controversial' (Stegemann \& Stegemann 1999:400). As Carter and Levine (2013:135) rightly affirm, as with all of Paul's letters, in this text we lack certainty in reconstructing the particular concerns of the recipients. We do not know what exactly was reported to Paul, or whether the information was accurate or complete; neither do we know the extent to which Paul reinterpreted the information he received. Hence, there are various approaches to the interpretation of the order that women should keep silence in the church. Some attempt to get round the problem by stating that this section is a later addition, not written by Paul. For example, MurphyO'Oconnor (1982:133) in his commentary on 1 Corinthians 14:26-40, leaves out verses 34 and 35 because he believes these verses were not written by Paul. He observes that 'If these verses are removed no violence is done to his (Paul's) argument. In fact, it gains in clarity'. The author seems to be correct here, for if the reader skips these two verses the instruction calling for orderly church service is not interrupted. Perhaps for this reason some manuscripts place the two verses at the end of the chapter (Carson et al. 1992:283). It is noteworthy, however, that while there is no absolute agreement on whether or not the two verses are rightly placed, every manuscript includes the injunction (Carson et al. 1992:283; Winter 1994:1182). And, as a matter of fact, that verses 34-35 appear in different locations in some early manuscripts may not necessarily prove that they are interpolations. It may simply indicate that 'the scribes felt that the verses were better placed elsewhere' (Carter \& Levine 2013:142).

Some scholars assert that the injunction in verses 1 Corinthians 14:34 and 35 could not have been written by Paul in view of its apparent contradiction with 1 Corinthians 11:5, 13 where Paul allows women to pray and prophesy in church provided they are veiled (Murphy-O'Oconnor 1982:133; Williams 1982:963). Others seek to abrogate 1 Corinthians 11:5, 13 to allow 1 Corinthians 14:34-35 to stand. According to Kugelman (1968:272), for example, Paul wants the church in Corinth to observe the prohibition of women from speaking publicly in the church, the prohibition which obtained in the Palestinian churches. Kugelman is of the view that by this injunction Paul abrogates the Corinthian practice of permitting women to prophesy in the church. But there are others who hold that Paul was the author of the two passages, and that they do not contradict each other. W.J. Sparrow Simpson (cited by Williams 1982:963) interprets 1 Corinthians 14:34-35 as forbidding women from speaking publicly in the church. Paul thought that women should in their subservience to men remain in a public service both covered and silent. Paul never contemplated women becoming priests or overseers, or even public preachers. Hodge (1974:304-305) also does not see the two texts as contradictory. In his own opinion 1 Corinthians 11:5 shows that Paul seems to take for granted that women might receive and exercise the gift of prophecy. The evangelist must have been aware of the prediction in the Old Testament that 'your sons and daughters shall prophesy' (Jl 2:28-32); the prediction which Peter quotes as fulfilled on the Day of Pentecost (Ac 2:14-17). Similarly, Hillyer (1970:1070) opines that in view of 1 Corinthians 11:5 Paul could not have condemned women to complete silence in the church. The injunction may have arisen from the fact that women, who sat apart from men in the church, were probably commenting freely and calling out questions in a disorderly manner (so also Powers 1996:180; Stegemann \& Stegemann 1999:369).

The view that the injunction must have arisen because of the fact that the women were probably causing disruption of church services seems plausible, and not a few other scholars share it. According to Keener (1993:483), in antiquity women were far less trained in the scriptures and public reasoning than men; at Corinth probably the women, in their bid to learn, were interrupting during the teaching period of the church service. Paul wanted this to stop, hence his order that they should learn at home under their husbands. Gutzke (1978:139) also believes that Paul's injunction may have been precipitated by the unruly behaviour of the female congregants, which would liken the Christian assembly to the pagan temples in Corinth where the notorious activity of women was a scandal. Paul probably thought that public decorum on the part of Christian women would improve the testimony of the gospel in the city. Gutzke however adds, 'that Paul did not forbid women to share in public worship services seems to be revealed in his writings elsewhere (Phil. 4:3)'. Carter and Levine (2013:142) are of the view that verses 34-35 are original to Paul but intended to stop women's speech. Paul had been discussing glossolalia. Perhaps women in Corinth had been among those exhibiting the gifts of tongue and prophecy. However, they do not see the injunction as applying to churches outside Corinth. 'Taking the verses as addressed specifically to the Corinthian church, perhaps only to wives and only concerning glossolalia, suggests that the verses do not apply in other contexts and churches'.

The intent of the order that women should keep silent en tais ekklesiais (v.34) seems clearer if the argument is approached from the perspective of the Greek term ekklesia. According to Baumert (1996:196), the term ekklesia (assembly, 
church) emanated from the secular realm, that is, the 'parliament' of a Greek city-state (cf. Ac 19:39). It is the political assembly of all (male) voting citizens in a city (Stegemann \& Stegemann 1999:262). As Stegemann and Stegemann (1999:275) affirm, ekklesia denotes the popular assembly of all voting free men, the full citizens of a polis. Women, children, slaves and foreigners were in any case excluded. Such assemblies took place regularly or extraordinarily. In its New Testament usage ekklesia refers to the Christ-confessing communities; it is applied to individual house members, to the area churches that perhaps consist of several house churches, and to all believers in Christ. This Jewish-Christian model, 'which most certainly did not admit women', was the decisive authority for the Christian community assembly (Baumert 1996:196). Similarly, the Hellenistic mystery cults distinguished between so-called executive meetings and the regular cultic assemblies, and probably maintained a similar distinction concerning the participation of women according to the type of meeting it was (Baumert 1996:196). Thus, given the Hellenistic environment, it would have been a progressive step in the Christian ekklesia to allow women to be present during discussions. Baumert attributes this to the new brotherhood and sisterhood in Christ, and also the greater independence of the Hellenistic woman. The form of Christian assembly in 1 Corinthians 14, therefore, constitutes the first step to allowing women's participation in 'council deliberations'. However, even on such occasions, the idea of a woman asking questions en ekklesia (i.e. in public, v.35), 'is (still) frowned upon, not only in Jewish circles but also in the Greek sphere' (Baumert 1996:196).

Thus, when Paul says in verse 35, 'For it is shameful for a woman to speak en ekklesia', he simply reminds the Corinthian Christian women of what applies in the contemporary society; there is no indication that he intends to cancel the privilege of speaking in church already being enjoyed by women. Therefore, the view that Paul's injunction is precipitated by the unruly behaviour of the female congregants is plausible to the present writer. In other words, the essence of the command is the disturbance being caused by the women, and not really the participation by them. This interpretation is supported by other facts already established. Firstly, most interpreters agree that 1 Corinthians 14:26-40 instructs on orderly service, which provides the relevant context for the suggestion of disorderly behaviour. We have also seen that Paul worked side by side with women in his ministry, in which they actually played leadership roles (cf. Carter \& Levine 2013:142). It is unlikely that the same Paul would condemn women to silence in the church except for the reason of disorderliness.

Some commentators (e.g. Winter 1994:1182) believe that the law referred to in verse 34 is Genesis 2:20-24 or 3:16. However, many are of the view that it does not refer to any specific commandment in the scriptures. It is most likely an invocation of a universal consensus, 'an unwritten law, so to speak', of Jewish custom (Baumert 1996:197; cf. Carter \& Levine 2013:142). Hence, as Baumert explains, Paul is here 'not referring to a revealed truth concerning the nature of men and women, but only a human code of conduct that is based on tradition and is thus naturally conditioned by the times' (Baumert 1996:197). In line with this reconstruction, Baumert paraphrases 1 Corinthians 14:33b-36 as follows:

${ }^{33 b}$ As in all the communities of the saints, ${ }^{34}$ women should keep
silent in the community assemblies; indeed, they are not permitted
(by the existing code) to speak. They should rather submit
themselves as the Jewish tradition decrees. ${ }^{35}$ However, should
they wish to inform themselves about something, they should
inquire of their men at home, for it is offensive to have a woman
speak her mind in public. ${ }^{36} \mathrm{Has}$ the word of God gone out from
you, or have only you received it? (Baumert 1996:197)

Thus, in 1 Corinthians 14:33b-36 Paul is saying that according to the universally known convention women are not permitted to voice their opinions in council, that is, publicly. He would rather have them silent than allow them to disrupt church services. It is important to note that Paul did not fundamentally question the entire code; neither did he 'think through our equality in Christ to its logical conclusion' (Baumert 1996:198). Paul did not do either of these because, like Jesus, his interest was not to change the social structure. Rather:

Paul has understood correctly that God's work of salvation is 'historical,' which means that it leaves a person in their situation, so as to allow them to make progress from the interior of their nature outward step by step. (Baumert 1996:198)

This means that in 1 Corinthians 14:33b-36 no essential code is being proclaimed. In the words of Baumert:

Paul only wants to make sure that the women do not do something that will generally be perceived as offensive.... And because it is improper and goes against the community order, people who engage in such activity are spiritually immature. Behind all this stands a fundamental principle: if the situation should change, you should do whatever will be perceived as appropriate! Thus, following this same principle, today not only would Paul not be against such 'participation' by women in discussions, he would rather insist upon it. (Baumert 1996:198)

In summary, in 1 Corinthians 14:33b-36, Paul apparently condemns women to silence in the church; but such a literal interpretation fails to consider a number of facts. The first one is that it contradicts the fact that women played significant public roles in Paul's ministry. More importantly, a study of the term ekklesia reveals that the text originated from a society in which ordinarily women were not allowed to participate in public discussions. This implies that in the Christian assemblies they were permitted on the basis of the brotherhood associated with the new religion. However, in the Corinthian church, women were abusing this privilege by disrupting church services, hence Paul's injunction. Therefore, the essence of the injunction is not the participation by women but the disorderliness being caused by them. In other words, in this text Paul does not intend to establish a doctrine disallowing women from participating in church affairs publicly, or in church leadership as some would think; only he would rather have them silent in the church than allow them disrupt its proceedings. 


\section{Implication for the Nigerian context}

The implication of this study for Nigeria is very clear. Denominations that still exclude women from leadership and participation in other spheres as a doctrine based on the 1 Corinthians 14 text need to have a rethink. In Nigeria, women constitute a very high percentage of church membership and are usually more active and regular in church activities than their male counterparts. It is they who dominate the choir, vigils, crusades, mid-week and other programmes. Aluko (1993:58) is therefore correct when he says that 'women are in the majority in most churches. It is therefore a disservice to the church if they are not given prominent leadership roles to play'. Awolalu (1976:103) also says that men should be more accommodating and less selfish in church affairs but encourage women to participate more in church leadership, as this will make the church richer and more edifying than they are at present. In line with this suggestion, every congregation should, in fact, identify talented young ladies to lead church programmes rather than leaving them passive. As Olajubu (1991:81) rightly observes, the few women preachers we have today have demonstrated that women, too, can do the work of evangelism as efficiently as men. They should, therefore, not be restricted any longer from occupying the pulpit. She admonishes that anywhere such a restriction still subsists it should be removed because sex should not be a barrier in the propagation of the gospel. Similarly, Odendaal (1994:256) is of the view that even though the Bible is exclusive in language and thought it should be made relevant to both sexes just as it has been made relevant to other times and societies. This can be done by engaging women actively in church activities.

It is interesting to note that even in Judaism from which Christianity inherited the male-domination practice, for some time, now it (Reformed Judaism) has allowed women to participate on equal terms in synagogues and, in many instances, to hold high office within the community. For example, in September 1972, Sally J. Preisand became the first female rabbi in the history of Judaism; and others such as Pauline Bebe have emerged after her (Van Der Stockt 2008). There is therefore no more basis for Nigerian churches to continue to exclude women from participating in church leadership.

\section{Conclusion}

1 Corinthians 14:33b-36 contains the injunction by the apostle Paul that women should keep silence in the church. This text has given rise to the controversy as to whether or not women should participate in church public activities or in its leadership. In the contemporary church, attitude to this rule varies from one denomination to another. In Nigeria, while in the Pentecostal and neo-Pentecostal folds women are generally included in the hierarchy of church leadership, many of the mainline churches still practise male domination, basing the doctrine on the Pauline injunction. An examination of the history of the Jews reveals that women had a very low status compared to men. They had very little or no chance to participate in religious leadership. However, the ministry of Jesus marked a change in the male-dominated social structure in that he related freely with women, treating them on equal basis with men. Paul built on this foundation, having many women as co-preachers and leaders of the house churches; which would contradict a literal interpretation of 1 Corinthians 14:33b-36.

However, the text is best understood from the perspective of the Greek term ekklesia in its popular context where it refers to the assembly of a Greek city-state. In such assembly women were not permitted at all to speak. In other words, the text originated from a society in which ordinarily women were not allowed to participate in public discussions, but in the Christian similar assemblies they were permitted on the basis of the brotherhood associated with the new religion. However, in the Corinthian church women were abusing this privilege by disrupting church services, which warranted the order by Paul. This means that the crucial issue in it is the disorderliness being caused by the women, and not the participation by them. Therefore, in this text it was not the intention of the author to establish a doctrine disallowing women from participating in church public worship, or in church leadership. Paul would rather have the women silent in the church than allow them disrupt its proceedings. The implication of this study for current practices in Nigeria is very clear. It is a doctrinal error to exclude women from church leadership and participation in other spheres based on 1 Corinthians 14:33b-36. Arising from this study, women participation should actually go beyond giving those titles and making them leaders of women guilds in the church. In Nigeria, women constitute the greater percentage of the congregation population; giving them the opportunity to participate in church leadership would provide the church with more hands in evangelism and expansion.

\section{Acknowledgements Competing interests}

The author declares that he has no financial or personal relationships which may have inappropriately influenced him in writing this article.

\section{References}

Ademiluka, S.O., 2007, Issues at stake in the contemporary Nigeria church, NATHDEX, llorin.

Aluko, T., 1993, 'Women and church growth in Yorubaland: An examination of their contributions', JARS: Journal of Arabic and Religious Studies 10, 53-61.

Awolalu, J.O., 1976, 'Women from the perspective of religion', Orita: Ibadan Journal of Religious Studies 10(2), 96-107.

Baumert, N.S.J, 1996, Woman and man in Paul: Overcoming a misunderstanding, transl. S.J.P. Madigan, \&L.M. Maloney, M. Glazier, Collegeville, MN.

Burrows, M., 1982, 'The social institutions of Israel', in M. Black \& H.H. Rowley (eds.), Peake's commentary on the bible, pp. 134-141, Van Nostrand Reinhold, Wokingham.

Carson, D.A., Moo, D.J. \& Morris, L., 1992, An introduction to the New Testament, Zondervan, Grand Rapids, MI.

Carter, W. \& Levine, A.-J., 2013, The New Testament: Methods and meanings, Abingdon Press, Nashville, TN.

Claassens, J.L., 2013, 'Female resistance in spite of injustice: Human dignity and the daughter of Jephthah', Old Testament Essays 26(3), 607-622.

Collins, S., 1972, 'Towards a feminist theology', Christian Century 89, 792-804. 
Gutzke, M.G., 1978, Plain talk on Corinthians, Zondervan, Grand Rapids, MI.

Hillyer, N., 1970, '1\&2 Corinthians', in D. Guthrie \& J.A. Motyer (eds.), The new bible commentary, pp. 1065-1073, Inter Varsity Press, Leicester.

Hodge, C., 1974, I \&// Corinthians, The Barner of Truth Trust, Edinburgh.

Hurley, J.B., 1975, Man and woman in biblical perspective, Inter Varsity Press, Leicester. Keener, C.S., 1993, The IVP bible background commentary: New Testament, IVP, Westmont, IL.

Kugelman, R.C.P., 1968, 'The first letter to the Corinthians', in E. Brown et al. (eds.), The Jerome Biblical commentary, pp. 268-275, Geoffrey Chapman, London.

Manson, T.W., 1982, 'Romans', in M. Black \& H.H. Rowley (eds.), Peake's commentary on the bible, pp. 940-954, Van Nostrand Reinhold, Wokingham.

Masenya, M., 2013, 'The dissolution of the monarchy, the collapse of the temple and the "elevation" of women in the post-exilic period: Any relevance for African women's theologies?' Old Testament Essays 26(1), 137-153.

Moo, D.J., 1994, 'Romans', in D.A. Carson et al.(eds.), New Bible commentary, pp. 1115-1160, IVP, Nottingham.

Murphy-O'Connor, J., 1982, 1 Corinthians, Michael Clazier, Wilmington, DE.

Odendaal, M.S., 1994, 'A feminist understanding of the Old Testament', Old Testament Essays 7(4), 254-258.
Olajubu, O., 1991, 'Women awareness and leadership in church structure in Nigeria', African Journal of Biblical Studies VI(1), 70-82.

Olajubu, O., 1993, 'The role of women in the New Testament as service to humanity', in R.D. Abubakre, E.A. Odumuyiwa \& M.O. Opeloye (eds.), Religion and service to humanity, pp. 138-145, Nigerian Association for the Study of Religions, llorin.

Omotoye, R., 1996-1999, 'Divine healing in Aladura Churches: A phenomenon of challenge to the mainline churches', JARS: Journal of Arabic and Religious Studies $13,60-69$.

Powers, W., 1996, The ministry of women in the church: Which way forward?, SPCK, Adelaide.

Shillington, V.G., 2008, The New Testament in context, T\&T Clark, London.

Stegemann, E.W. \&Stegemann, W., 1999, The Jesus movement: A social history of its first century, transl. O.C. Dean, Jr., Fortress Press, Minneapolis, MN.

Van Der Stockt, L., 2008, 'Women in Judaism', Encarta Encyclopedia, Microsoft Corporation, Washington.

Williams, C.S.C., 1982, 'I \& II Corintihians', in M. Black \& H.H. Rowley (eds.), Peake's commentary on the bible, pp. 954-972, Van Nostrand Reinhold, Wokingham.

Winter, B., 1994, '1 Corinthians', in D.A. Carson et al. (eds.), New Bible Commentary, pp. 1161-1187, Inter-Varsity, Leicester. 